\title{
Preservice Physical Education Teachers' Perceptions of Competence in Selecting Teaching Techniques: Teacher Training in Turkey
}

\author{
Mehmet Yanık (Corresponding author) \\ Faculty of Sport Science, Balikesir University, Balikesir, Turkey \\ Tel: 90-505-670 7172 E-mail: mehmetyanik@balikesir.edu.tr
}

Received: May 2, 2020 Accepted: May 31, 2020 Published: June 3, 2020

doi:10.5296/jei.v6i1.16951 URL: https://doi.org/10.5296/jei.v6i1.16951

\begin{abstract}
The aim of this study was to examine preservice physical education teachers' perceived competence in selecting teaching techniques according to certain variables. The research was designed as a descriptive study using a screening model. The study universe consisted of a total of 348 preservice physical education teachers studying in different departments. The "Scale of Preservice Teachers' Perceived Competence in Selecting Teaching Techniques" was used as the data collection tool. For analysis of the data, frequency and percentage distribution, arithmetic mean, standard deviation, t-test and one-way analysis of variance values were used. The level of significance was taken as $p<0.05$ for all tests. The results obtained in the study revealed that according to the evaluation of the scale score intervals, the participants' mean scores $(4.24 \pm 0.36)$ for perceptions of competence in selecting teaching techniques were high. According to the subdimensions, mean scores of $4.30 \pm 0.38$ in the positive prediction subdimension and $4.11 \pm 0.39$ in the negative prediction subdimension were obtained. No difference was found between groups according to the gender variable. According to the variable for type of department attended, it was seen that students in the coaching department who obtained the right to become teachers via certificate programmes had lower perception levels. Another finding of the study was that as grade level increased, participants' levels of perceived competence increased. As a result of the research, recommendations are offered regarding the need for preservice teachers, from their selection onwards, to be educated with programmes which give priority to domain-specific practices, and for certificate programmes that grant the right to become a teacher through short-term training to be reviewed.
\end{abstract}

Keywords: Teacher training, Preservice teacher, Certificate programme 


\section{Introduction}

The education of individuals with life skills for the 21 st century can be possible by carrying out education programmes that have correctly-determined goals and well-planned processes. Achieving the determined goals of education programmes depends on a number of factors working in coordination with each other. The success of education programmes that have all the mutually dynamic relationships between a number of components, such as near and distant targets, content and evaluation, depends on the correct use of the teaching methods and techniques that will be used in the process (Kubat, 2016; Demir \& Özden, 2013).

Even if education programmes are organised in such a way as to enable the determined goals to be achieved, the actual responsibility falls on the teachers who are the in-process implementers of the programmes. Teachers should possess the ability to make a series of decisions, such as planning instruction, selecting content and setting course objectives (König, Bremerich-Vos, Buchholtz, Fladung, \& Glutsch, 2020). Moreover, teachers need to have adequate knowledge and skills related to the model, strategies, methods and techniques that will achieve the outcomes they have determined.

Many definitions are made related to the concept of education nowadays. In a traditional sense, education is "the process of changing an individual's terminal and intentional behaviour through his/her experiences". According to contemporary approaches, however, it is defined as "the process of improving an individual's life quality". Accordingly, teachers must be able to improve the individual not only regarding the objectives of formal education programmes but also individuals' life quality within the informal education process. Therefore, a teacher should also possess good pedagogical knowledge (Soytürk, 2019).

In modern-day education practices, the use of contemporary teaching methods and models, which place the student at the centre of practices, increases the effectiveness of learning. In education practices for this purpose, the teacher's guidance of the process and the student's use of his/her cognitive skills have become the most important objective (Demirkan \& Saraçoğlu, 2016). Structured curricula have begun to be applied in Turkey in the last 20 years. Structured curricula are a student-centred approach implemented in many countries of the world (Çiftçi, Sünbül, \& Köksal, 2013; Akçay, Doymuş, Şimşek, \& Okumuş, 2012).

It is known that teachers who conduct the process with a traditional understanding are lacking in terms of using teaching methods and techniques, and that they conduct a teacher-centred process with a fear of losing control of the class (Y1lmaz, Aslan, \& Ayan, 2020). For students to be able to conduct a process in which they are at the centre, their teachers also need to be well educated. It is very important in this respect for the quality of professional training of preservice teachers to be increased. In addition to candidates' theoretical education, it is essential that field practice training is also given (Demircioğlu, Genç, \& Demircioğlu, 2015).

Since physical education lessons are primarily practical, they are considered to be structured on the development of physical and motor skills in the individual. However, physical education lessons also have the objective of developing individuals' cognitive and affective characteristics. Therefore, a number of different teaching techniques are used in physical 
education teaching. In a study carried out by Mosston and Ashworth (2008), the methods and techniques used in regard to physical education teaching were organised systematically. In the literature, it is seen that numerous studies have been conducted related to the use of teaching techniques in physical education practices (Casey \& MacPhail, 2018; Syrmpas, Digelidis, \& Watt, 2016; Parker \& Curtner-Smith, 2012). As a common finding of these studies, conducting lesson practices with approaches in which the student is at the centre and active is considered to be important. For this purpose, teacher training programmes need to be organised in such a way as to support this approach (Oddens, 2004).

In order to plan the teaching-learning process well and to enable the student outcomes included in the curriculum to be achieved, teachers should possess the competence to learn and use the teaching strategies, methods and techniques. Effective teaching depends on the ability to use various teaching techniques in accordance with the teaching objectives and students' characteristics. The ability to create such an environment depends on how high teachers' levels of professional competence are.

When considered from the viewpoint of meeting teachers' needs, two different implementations are made in Turkey. The first of these are the teacher training programmes conducted in education faculties. The second are the programmes with which graduates of four-year courses in different faculties can obtain their teaching certificate with short-term programmes. Deficiencies of practice are experienced in these programmes. In teacher training, the practica support candidates' development in becoming professional teachers and provide them with experiential skills (Kaldi, 2009; Farrell, 2008). Moreover, practices such as these are activities that will improve the quality of the education system (Hegender, 2010; Goodwin \& Oyler, 2008).

The selection of suitable candidates is essential for the teaching profession (Mankki, Makinen, $\&$ Raiha, 2020). While many countries have difficulty in finding prospective teachers (OECD, 2015), in Turkey, the teaching profession, especially physical education teaching, is regarded as an attractive field by many young people. Teaching programmes for training physical education teachers cover a four-year period. Selection of students for these programmes differs from that in other areas. Candidates wishing to study on these programmes are placed on the programmes by going through specially designed exam stages. In Turkey, physical education teachers are appointed in two different ways. One of these are domain-specific teaching programmes, while in the other, students studying in the coaching, sports management and recreation departments at the same faculties obtain their teaching certificate via short-term programmes.

Therefore, the aim of this study is to determine perceptions of competence in selecting teaching techniques among prospective teachers studying in the physical education teaching department and the coaching department of the relevant faculties, and, based on the results obtained, to make recommendations related to the learning processes of the candidates. 


\section{Method}

\subsection{Research Model}

The research is a descriptive study which uses a screening model to determine and compare preservice physical education teachers' perceptions of their competence to teach.

\subsection{Study Group}

The study group of the research consists of a total of 348 preservice physical education teachers studying at the sport sciences faculty in Balikesir University and who obtain their teaching certificates with two different types of education.

Table 1. Demographic information about the participants

\begin{tabular}{|c|c|c|c|c|}
\hline Variables & \multicolumn{2}{|l|}{ Groups } & $(\mathrm{N})$ & (F) $\%$ \\
\hline \multirow{2}{*}{ Gender } & \multicolumn{2}{|l|}{ Female } & 121 & 34.8 \\
\hline & \multicolumn{2}{|l|}{ Male } & 227 & 65.2 \\
\hline \multirow{8}{*}{ Grade } & \multirow{2}{*}{ First Grade } & PES Teaching & 35 & \multirow{2}{*}{27.6} \\
\hline & & Coach Teaching & 61 & \\
\hline & \multirow{2}{*}{ Second Grade } & PES Teaching & 30 & \multirow{2}{*}{24.0} \\
\hline & & Coach Teaching & 56 & \\
\hline & \multirow{2}{*}{ Third Grade } & PES Teaching & 28 & \multirow{2}{*}{22.4} \\
\hline & & Coach Teaching & 50 & \\
\hline & \multirow{2}{*}{ Fourth Grade } & PES Teaching & 30 & \multirow{2}{*}{25.3} \\
\hline & & Coach Teaching & 58 & \\
\hline \multicolumn{3}{|l|}{ Total } & 348 & 100.0 \\
\hline
\end{tabular}

Note. PES: Physical education and sports teaching.

\subsection{Data Collection Tools}

The research data were gathered using the "Scale of Preservice Teachers' Perceived Competence in Selecting Teaching Techniques" developed by Durdukoca, Yardımciel, Beşeren, and Özbek (2017). The scale has a two-factor structure consisting of positive predictions (items 1-15) and negative predictions (items 16-22). It is a 5-point Likert-type scale comprising a total of 22 items. Internal consistency coefficients of the scale were determined as 0.90 for the whole scale, and 0.92 and 0.82 for the subdimensions, respectively.

According to the reliability analysis made for this study, the internal consistency coefficients 
were 0.84 for the first factor, 0.74 for the second factor, and 0.89 for the whole scale. Considering that in studies related to reliability, coefficients of 0.65 and over are sufficient (Cronbach, 1990), it is seen that the reliability level of the scale and its constituent items is adequate.

\subsection{Data Analysis}

The data obtained within the scope of the research were analysed using SPSS software. At the stage of determining the suitable type of analysis for evaluation of the data, the number of subjects $(n=348)$ and whether or not the data showed normal distribution and had a homogeneous structure were examined. It was seen that the data met the parametric test assumptions.

The data were analysed using descriptive statistical methods, t-test and one-way analysis of variance (ANOVA). To determine the groups from which significant differences emerged, the Tukey multiple comparison test was performed. The level of significance was taken as $\mathrm{p}<$ 0.05 for all tests.

\section{Findings}

The results of the analysis made in the study to determine the participants' perceived competence in selecting teaching techniques reveal that according to the evaluation of the scale score intervals, the participants' mean scores $(4.24 \pm 0.36)$ for perceptions of competence in selecting teaching techniques were high.

In the analysis made for the subfactors of the scale, participants' mean score for the subfactor of positive predictions related to perceived competence in selecting teaching techniques was $4.30 \pm 0.38$, while their mean score for the negative predictions subfactor was $4.11 \pm 0.39$.

Results of the test analysis for participants' levels of perceived competence in selecting teaching techniques according to the gender variable are given in Table 2.

Table 2. Score analysis of participants' perceived competence in selecting teaching techniques according to "gender" variable

\begin{tabular}{|l|l|l|l|l|}
\hline Scale subfactor & Female $(\mathrm{n}=121) \overline{\mathrm{x}} \pm$ St.d & Male $(227) \overline{\mathrm{x}} \pm$ St.d & $\mathrm{t}$ & $\mathrm{p}$ \\
\hline Positive Predictions & $4.27 \pm 0.34$ & $4.32 \pm 0.40$ & 1.25 & .20 \\
\hline Negative Predictions & $4.10 \pm 0.36$ & $4.11 \pm 0.40$ & .008 & .99 \\
\hline Total & $4.22 \pm 0.33$ & $4.25 \pm 0.38$ & .896 & .37 \\
\hline
\end{tabular}

As seen in Table 2, it was determined that participants' levels of perceived competence in selecting teaching techniques did not differ according to the gender variable in terms of either total scores or scores for the subdimensions $(p>0.05)$. 
Results of the test analysis for participants' levels of perceived competence in selecting teaching techniques according to the variable of department attended are given in Table 3.

Table 3. Score analysis of participants' perceived competence in selecting teaching techniques according to "Department" variable

\begin{tabular}{|l|l|l|l|l|}
\hline Scale subfactor & PES Teaching $(\mathrm{n}=123) \overline{\mathrm{x}} \pm$ St.d & Coach Teaching $(\mathrm{n}=225) \overline{\mathrm{x}} \pm$ St.d & $\mathrm{t}$ & $\mathrm{p}$ \\
\hline Positive Predictions & $4,39 \pm 0,34$ & $4,26 \pm 0,39$ & 3,01 &, 003 \\
\hline Negative Predictions & $4,19 \pm 0,35$ & $4,06 \pm 0,40$ & 3,10 &, 002 \\
\hline Total & $4,32 \pm 0,32$ & $4,19 \pm 0,38$ & 3,19 &, 002 \\
\hline
\end{tabular}

Note. PES: Physical education and sports teaching.

As can be seen in Table 3, according to the results of the analysis made for the "department" variable, a significant difference in participants' levels of perceived competence in selecting teaching techniques was seen between groups [ $\mathrm{t}(346)=3.19, \mathrm{p}<0.001]$.

ANOVA test analysis was performed to determine differences in participants' levels of perceived competence in selecting teaching techniques according to the "grade level" variable. The findings are reported in Table 4.

Table 4. Score analysis of participants' perceived competence in selecting teaching techniques according to "Grade Level" variable

\begin{tabular}{|c|c|c|c|c|c|c|c|c|}
\hline Grade Level & $\mathrm{n}$ & $\overline{\mathrm{x}} \pm \mathrm{Ss}$ & & Ss & $\mathrm{df}$ & Ms & $\mathrm{F}$ & $\mathrm{p}$ \\
\hline First Grade & 96 & $3.94 \pm 0.29$ & Between Group & 19.67 & 3 & 6.55 & \multirow[t]{5}{*}{81.85} & \multirow[t]{5}{*}{0.00} \\
\hline Second Grade & 86 & $4.11 \pm 0.31$ & Within Group & 27.56 & 344 & 0.80 & & \\
\hline Third Grade & 78 & $4.44 \pm 0.21$ & Totaly & 47.24 & 347 & & & \\
\hline Fourth Grade & 88 & $4.51 \pm 0.29$ & & & & & & \\
\hline Total & 348 & $4.24 \pm 0.36$ & & & & & & \\
\hline
\end{tabular}

As can be seen in Table 4, a statistically significant difference at $\mathrm{p}<0.05$ level was determined between groups $\left[\mathrm{F}_{(3.344)}=81.85, \mathrm{p}<0.05\right]$. According to the results of the multiple comparison test (post-hoc Tukey) carried out to determine the source of this difference, it was seen to be due to the fact that results for participants studying in first grade $(3.94 \pm 0.29)$ were lower than those for other grade levels. 


\section{Discussion}

Together with the constant updating of knowledge nowadays, the training of individuals who can keep up with these innovations has become imperative. The most important role in fostering these qualities undoubtedly belongs to teachers, who are in the position of implementers of the education processes. Competence in learning how to learn, problem solving, critical thinking and using technology that individuals need to possess have come to the fore as 21 st-century skills that need to be fostered in students. Individuals who possess these skills are the most important elements that will form societies' future vision. Teachers bear great responsibility for nurturing universal values in societies in the long term with the students that they educate well. Therefore, it is essential that higher education institutions that train teachers can foster the necessary skills for preparing prospective teachers for the profession (Soytürk \& Öztürk, 2019)

Teacher training is built on two components, namely general and special area. In general training, teacher candidates are taught general subjects related to the teaching profession. In the special area component, however, an attempt is made to enable preservice teachers to acquire theoretical and practical skills specific to their own fields. In this study, the aim was to examine perceptions of competence in selecting teaching techniques in physical education teachers trained with two different programmes according to the teacher training system in Turkey.

According to the evaluation of the scale score intervals of the mean scores in the "Scale of Preservice Teachers' Perceived Competence in Selecting Teaching Techniques", the participants' levels of perceived competence in selecting teaching techniques were high. According to the results of the analysis of the subfactors that was made, it was seen that scores in the "positive predictions regarding selection of techniques" subfactor and the "negative predictions regarding selection of techniques" subfactor were also high. Success in the teaching profession is associated with a number of components. One of these components is positive attitudes felt towards the profession. It is thought that this result will have a positive effect on candidates' professional success.

In some societies nowadays, gender discrimination appears as an obstacle in choice of profession and career development (Duru, Bayraktar, \& Gültekin, 2020). However, it is thought that the teaching profession is perceived as a more suitable profession for women due to the convenient working hours and greater interaction with children. In the present study, according to the results of the test analysis made to reveal the participants' perceived competence in selecting teaching techniques in terms of the gender variable, a significant difference was not determined in scores for the whole scale or subdimensions of the scale.

Studies are found in the literature which support this finding. In a study conducted by Y1lmaz, Aslan, and Ayan (2020) with students in the sport sciences faculty, it was stated that no significant different was found in participants' competence for selecting teaching techniques according to the gender variable. In their study conducted with preservice teachers, Çimen and Yilmaz (2013) determined that gender had no effect on the prospective teachers' competence in teaching methods and techniques. 
For their individuals to acquire their own terminal behaviours and to achieve the determined objectives, societies are required to increase the capacities of teachers, who are an important element of the process, and to keep their knowledge up to date. For this reason, increasing and improving the quality of teachers, principally via the teacher training system, must be dealt with from a holistic perspective (ÖYGGM, 2017).

In the current study, a significant difference was seen in perception levels related to competence in selecting teaching techniques among preservice teachers who were trained in the two different models. Perceived competence was seen to be lower in participants who gained the right to become teachers through certificate programmes. Participants who study in the teaching department take long-term and practical courses that include special area knowledge, as required in their programmes. Students in the coaching department, however, mainly take courses specific to their branch. This situation is considered to be the reason for the study findings.

According to the results of the analysis made to determine the participants' perceived competence for selecting teaching techniques in terms of grade level, which was another variable in the study, a statistically significant difference was found. This difference was seen to be due to the fact that results for participants studying in first grade were lower than those for other grade levels. Moreover, it was observed that participants' perceptions of competence increased as their grade level increased.

Every country has different programmes related to teacher training in line with their own dynamics. Candidates go through several stages in order to become teachers. Generally, prior to taking up their duties as a teacher, candidate teachers are accompanied in their work by school counsellors. In Finland, teacher training varies according to subject area. While written and oral exams are carried out for selection of preservice teachers, all teachers have a postgraduate academic degree (Katriina, Heikki, Reijo, Riitta, \& Sara, 2019). Similarly, in the Netherlands, teacher training varies according to the educational level at which one's career is to be pursued. In order to work as teachers at the secondary level of education, candidates must complete their postgraduate education (Meens \& Bakx, 2019; Ergun \& Ersoy, 2014). In Japan, after candidates have completed their internships, they gain the right to become teachers according to the results of the exam that they enter (R. Uçar \& I. H. Uçar, 2004). In China, in order to become teachers, candidates can receive education from alternative institutions besides education faculties (Polat \& Arabac1, 2012).

In Germany, preservice teachers must graduate from a system consisting of two stages, which are theoretical and practical. After candidates have graduated from academic programmes in their universities, they work part time in schools as teacher candidates. Here, they receive practical training related to lesson planning, classroom management and how these are to be reflected in instruction. They attend general and domain-specific pedagogy courses. They are awarded their certificates after oral and practical examinations given by the state (König \& Blömeke, 2013).

In Turkey, however, there are sufficient teacher candidates who graduate from the related faculties to meet the need for teachers in the existing system. Yet from 2010 onwards, as a 
national policy, graduates from different faculties have been able to attend short-term pedagogical training programmes and obtain a teaching certificate. All candidates who have the right to be teachers are employed in state schools according to the results of written exams and interviews. In private institutions, the results of these exams are not important.

The fact that every country carries out different practices for teacher training according to their own dynamics has become a controversial issue (Hansen, Forsman, Aspfors, \& Bendtsen, 2011). However, the quality of pedagogical programmes and countries' education policies are considered to be key elements in determining teachers' real achievements.

\section{Conclusion and Recommendations}

The aim of this study was to compare levels of perceived competence for selecting teaching techniques among preservice physical education teachers trained with different training programmes. The study findings revealed that participants who studied in different departments and gained the right to become teachers via certificate programmes had lower perception levels than those of preservice teachers studying in the physical education teaching department. Significant differences were determined between the two groups. As a national policy, success in written exams and oral interviews by prospective teachers who have lower perceptions of their competence to select teaching techniques is also considered to be sufficient for them to begin their careers as teachers. It is considered that this situation will lead to deficiencies in their teaching experiences.

Based on these ideas, the following recommendations are advanced:

- The need for teachers should be met through existing teacher training colleges.

- If certificate programmes continue to be applied, their duration should be extended.

- Priority should be given to teaching practice courses in certificate programmes.

- Curricula should be updated in such a way as to increase candidates' perceptions of competence.

\section{References}

Akçay, N. O., Doymuş, K., Şimşek, Ü., \& Okumuş, S. (2012). The effect of cooperative learning model on academic achievement in physics. Energy Education Science and Technology Part B-Social and Educational Studies, 4(4), 1915-1924.

Casey, A., \& MacPhail, A. (2018). Adopting a models-based approach to teaching physical education. Physical Education and Sport Pedagogy, 23(3), 294-310. https://doi.org/10.1080/ 17408989.2018.1429588

Çiftçi, S., Sünbül, A., \& Köksal, O. (2013). An assessment of elementary school teachers' approaches and practices regarding the constructivist program based on the views of educational inspectors. Mersin University Journal of the Faculty of Education, 9(1), 281-295. https://doi.org/10.5505/pausbed.2013.39974

Çimen, O., \& Y1lmaz, M. (2013). An investigation of biology preservice teachers' 
self-efficacy beliefs regarding the application of teaching methods and techniques. Gazi University Journal of the Faculty of Education, 33(1), 51-65.

Cronbach, L. J. (1990). Essentials of psychological testing (5th ed.). New York: Harper Collins Publishing.

Demir, S., \& Özden, S. (2013). Primary school teachers' opinions of instructional strategies, methods and techniques: A descriptive study for science of life class. Pamukkale University the Journal of Social Sciences, 14, 59-75. https://doi.org/10.5505/pausbed.2013.39974

Demircioğlu, İ. H., Genç, İ., \& Demircioğlu, E. (2015). Knowledge level evaluation of the social studies pre-service teachers on teaching strategy, method and techniques. Abant Izzet Baysal University Journal of the Faculty of Education, 15, 18-34.

Demirkan, Ö., \& Saraçoğlu, G. (2016). Views of Anatolian high school teachers about teaching methods and techniques they use in class. The Journal of International Lingual Social And Educational Sciences, 2(1), 1-11.

Durdukoca, Ş. F., Yardımciel, E., Beşeren, H., \& Özbek, S. (2017). The perception scale of teachers' applicant's capacity to choose teaching techniques. Electronic Journal of Social Sciences, 16(61), 397-411. https://doi.org/10.17755/esosder.304682

Duru, H., Bayraktar, M., \& Gültekin, F. (2020). Analysis of teacher candidates career decisions from career barriers and career future perspective. Kastamonu Education Journal, 28(2), 613-629. https://doi.org/10.24106/kefdergi.693421

Ergun, M., \& Ersoy, Ö. (2014). Comparison of primary teacher education systems in the Netherlands, Romania and Turkey. Kastamonu Education Journal, 22(2), 673-700.

Farrell, T. S. C. (2008). Here's the book, go teach the class: ELT practicum support. RELC Journal, 39(2), 226-241.https://doi.org/10.1177/0033688208092186

Goodwin, L. A., \& Oyler, C. (2008). Teacher Educators as Gatekeepers: Deciding Who Is Ready to Teach. In I. M. Cochran-Smith, S. Feiman-Nemser, D. J. McIntyre, \& K. E. Demers (Eds.), Handbook of Research on Teacher Education: Enduring Questions in Changing Contexts (pp. 468-489). New York, NY: Routledge.

Hansèn, S. E., Forsman, L., Aspfors, J., \& Bendtsen, M. (2011). Visions for Teacher Education-Experiences from Finland. Acta Didactica, 6(1), 1-17. https://doi.org/10.5617/ adno. 1079

Hegender, H. (2010). The Assessment of Student Teachers' Academic and Professional Knowledge in School-Based Teacher Education. Scandinavian Journal of Educational Research, 54(2), 151-171. https://doi.org/10.1080/00313831003637931.

Kaldi, S. (2009). Student Teachers' Perceptions of Self-competence in and Emotions/Stress about Teaching in Initial Teacher Education. Educational Studies, 35(3), 349-360. https://doi.org/10.1080/03055690802648259

Katriina, M., Heikki, K., Reijo, B., Riitta, J., \& Sara, S. (2019). Teacher education matters: 
Finnish teacher educators' concerns, beliefs, and values, European Journal of Teacher Education, 42(2), 211-227. https://doi.org/10.1080/02619768.2019.1566317

König, J., \& Blömeke, S. (2013). Preparing teachers of mathematics in Germany. TEDS-M Encyclopaedia: A guide to teacher education context, structure, and quality assurance (p. 17).

König, J., Bremerich-Vos, A., Buchholtz, C., Fladung, I., \& Glutsch, N. (2020). Pre-service teachers' generic and subject-specific lesson-planning skills: on learning adaptive teaching during initial teacher education, European Journal of Teacher Education, 43(2), 131-150. https://doi.org/10.1080/02619768.2019.167911

Kubat, U. (2016). Determination of the techniques and methods used by pre-service science teachers in learning- teaching process and their aims. Qualitative Studies, 11(4), 39-47. https://doi.org/10.12739/NWSA.2016.11.4.E0027

Mankki, V., Makinen, M., \& Raiha, P. (2020). Teacher educators' predictability and student selection paradigms in entrance examinations for the Finnish Primary School Teacher Education programme, European Journal of Teacher Education, 43(2), 151-164. https://doi.org/10.1080/02619768.2019.1672653

Meens, E. E. M., \& Bakx, A. W. E. A. (2019). Student teachers' motives for participating in the teacher training program: a qualitative comparison between continuing students and switch students, European Journal of Teacher Education, 42(5), 650-674, https://doi.org/10.1080/ 02619768.2019.1652900

Mosston, M., \& Ashworth, S. (2008). Teaching Physical Education (1st ed.). Pearson Education. Retrieved from http://www.spectrumofteachingstyles.org/pdfs/ebook/Teaching Physical_Edu_1st_Online_old.pdf

Oddens, D. A. M. (2004). Trend in ducth vocational education teacher training in terms of personal quality. In International Conference on VET Teacher Training. VET Teacher Training (Vol. 1, pp. 347-354). Ankara: SVET.

OECD. (2015). Who Wants to Become a Teacher? Paris: OECD Publishing.

ÖYGGM. (2017). Öğretmen Strateji Belgesi 2017-2023 (Teacher Strategy Document). Retrieved April 23, 2020, from https://oygm.meb.gov.tr/www/ogretmen-strateji-belgesi/ icerik/406

Parker, M., \& Curtner-Smith, M. (2012). Preservice teachers' use of production and reproduction teaching styles within multi-activity and sport education units. European Physical Education Review, 18(1), 127-143. https://doi.org/10.1177/1356336X11430655

Polat, M., \& Arabac1, İ. B. (2012). Reconsideration of student enrolling criteria to schools of education in turkey: A Comparative Approach. Journal of Research in Education and Teaching, 1(3), 77-83.

Soytürk, M. (2019). Analysis of self and peer evaluation in basic volleyball skills of physical education teacher candidates. Journal of Education and Learning, 8(2), 256-263. 
https://doi.org/10.5539/jel.v8n2p256

Soytürk, M., \& Öztürk, Ö. T. (2019). An investigation of the attitudes and competence perceptions of first-and fourth-year pre-service physical education teachers regarding teaching. Journal of Education and Training Studies, 7(4), 154-159. https://doi.org/10.11114/ jets.v7i4.4141

Syrmpas, I., Digelidis, N., \& Watt, A. (2016). An examination of Greek physical educators' implementation and perceptions of Spectrum teaching styles. European Physical Education Review, 22(2), 201-214. https://doi.org/10.1177/1356336X15598789

Uçar, R., \& Uçar, İ. H. (2004). A study on education system of japan: comparison with Turkish education system in many respects. Yüzüncü Yll University Journal of the Faculty of Education, 1(1).

Y1lmaz, A., Aslan, E., \& Ayan, S. (2020). Teachers' Self-Efficacy Beliefs of Sport Science Faculty Students and Competence to Choose Teaching Techniques. MANAS Journal of Social Studies, 9(1), 435-448.https://doi.org/10.33206/mjss.502659

\section{Copyright Disclaimer}

Copyright for this article is retained by the author(s), with first publication rights granted to the journal.

This is an open-access article distributed under the terms and conditions of the Creative Commons Attribution license (http://creativecommons.org/licenses/by/3.0/). 